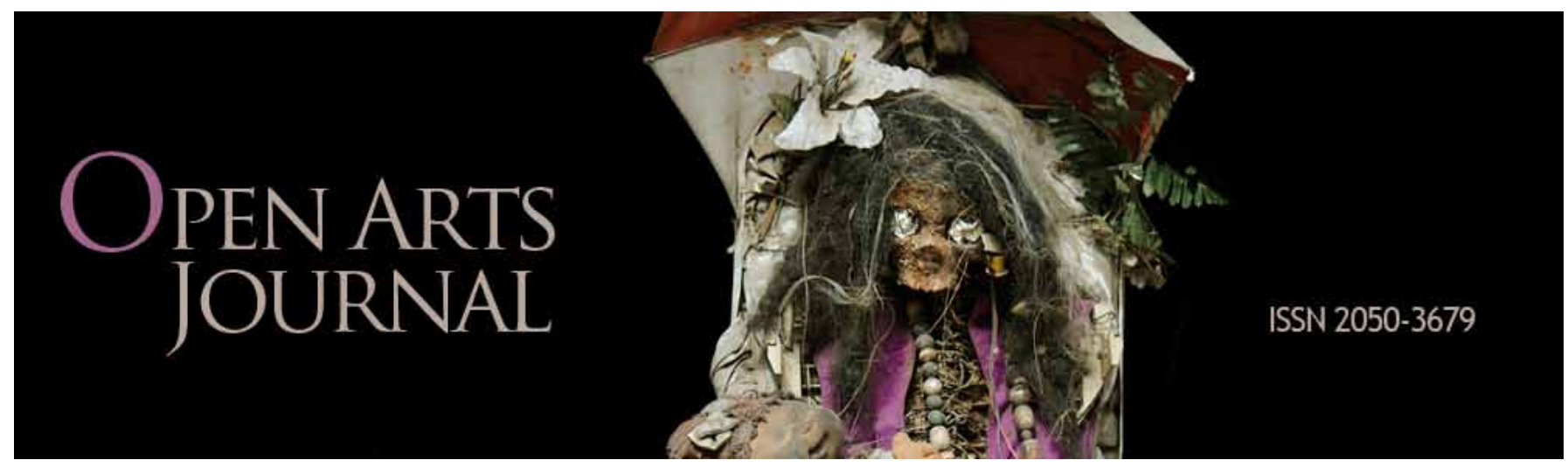

\title{
ON PENELOPE CURTIS'S PATIO AND PAVILION: THE PLACE OF SCULPTURE IN MODERN ARCHITECTURE Brian Hatton
}

This essay is an engagement with Penelope Curtis's book Patio and Pavilion (2007) and it expands on the significance of some of the points made there. Hatton explores the relationship between the artwork (mostly examples of sculpture) and the architectural stage where it is displayed, which is often a pavilion. This binary of container and contained is deconstructed in the work of a number of architects or artists, from Ludwig Mies van der Rohe's 1929 Barcelona Pavilion through to the glass pavilions of Dan Graham, where the pavilion itself is the primary object of display.

Keywords: pavilion, sculpture, installation, display, Penelope Curtis, Mies, Dan Graham.

Brian Hatton is a lecturer at the Architectural Association in London and the Liverpool John Moores University. In 2009 he was Senior Mellon Fellow at the Canadian Centre for Architecture, and with a grant from the Graham Foundation, is working on the theme 'Wandering and the Subject of the Open Plan'.

On Penelope Curtis's Patio and Pavilion:The Place of Sculpture in Modern Architecture (Brian Hatton, Architectural Association and Liverpool John Moores University)

DOI: http://dx.doi.org/I0.5456/issn.2050-3679/20I3w07bh

To view the images used in this article in a larger and more detailed format, follow this link: http://openartsjournal.org/issue-2/issue-2-galleries/article-6 
ON PENELOPE CURTIS'S PATIO AND PAVILION:THE PLACE OF SCULPTURE IN MODERN ARCHITECTURE

\section{Brian Hatton}

\section{Abstract}

This essay is an engagement with Penelope Curtis's book Patio and Pavilion (2007) and it expands on the significance of some of the points made there. Hatton explores the relationship between the artwork (mostly examples of sculpture) and the architectural stage where it is displayed, which is often a pavilion. This binary of container and contained is deconstructed in the work of a number of architects or artists, from Ludwig Mies van der Rohe's 1929 Barcelona Pavilion through to the glass pavilions of Dan Graham, where the pavilion itself is the primary object of display.

In her book Sculpture 1900-1950 (1999), Penelope Curtis described changes in where sculpture was thought to belong in the modernist era. Rather than as a public art, sculpture came to be regarded as best experienced in an intimate ambience - best of all in studio itself, as in Brancusi's den in Paris, now part of the Centre Georges Pompidou. Alternatively, sculpture left the building altogether for the park. The studio might be seen as an antecedent to 'installation', where a work expands to fill its housing, while 'park works' would mutate during the $60 \mathrm{~s}$ into 'earthworks'. Such works, as Rosalind Krauss pointed out in her essay 'Sculpture in the Expanded Field' (1979), are not modes of monument or 'landscaping', but occupy a new category of structural location - a location which Robert Smithson termed 'site', in dialectic relation to the 'non-site' of the gallery. Such locations cannot be identified with traditional sites of significance; for today, as art theorist Thierry de Duve has observed, 'there are no more sites' (De Duve, 1993, pp.25-30). Moreover, even where a work is called 'site-specific', it may colonize its 'host' indifferently, ignoring, or - in artist Gordon Matta-Clark's works - subverting its significance. We may say of such works that they occupy the physical but not the symbolic space of architecture. Likewise they elude the gallery, and for this reason an entire category of artwork has appeared in recent years, which can never (except as documentary record) be brought into a gallery or museum. Meanwhile, the museum itself has become more like a park, an evolving

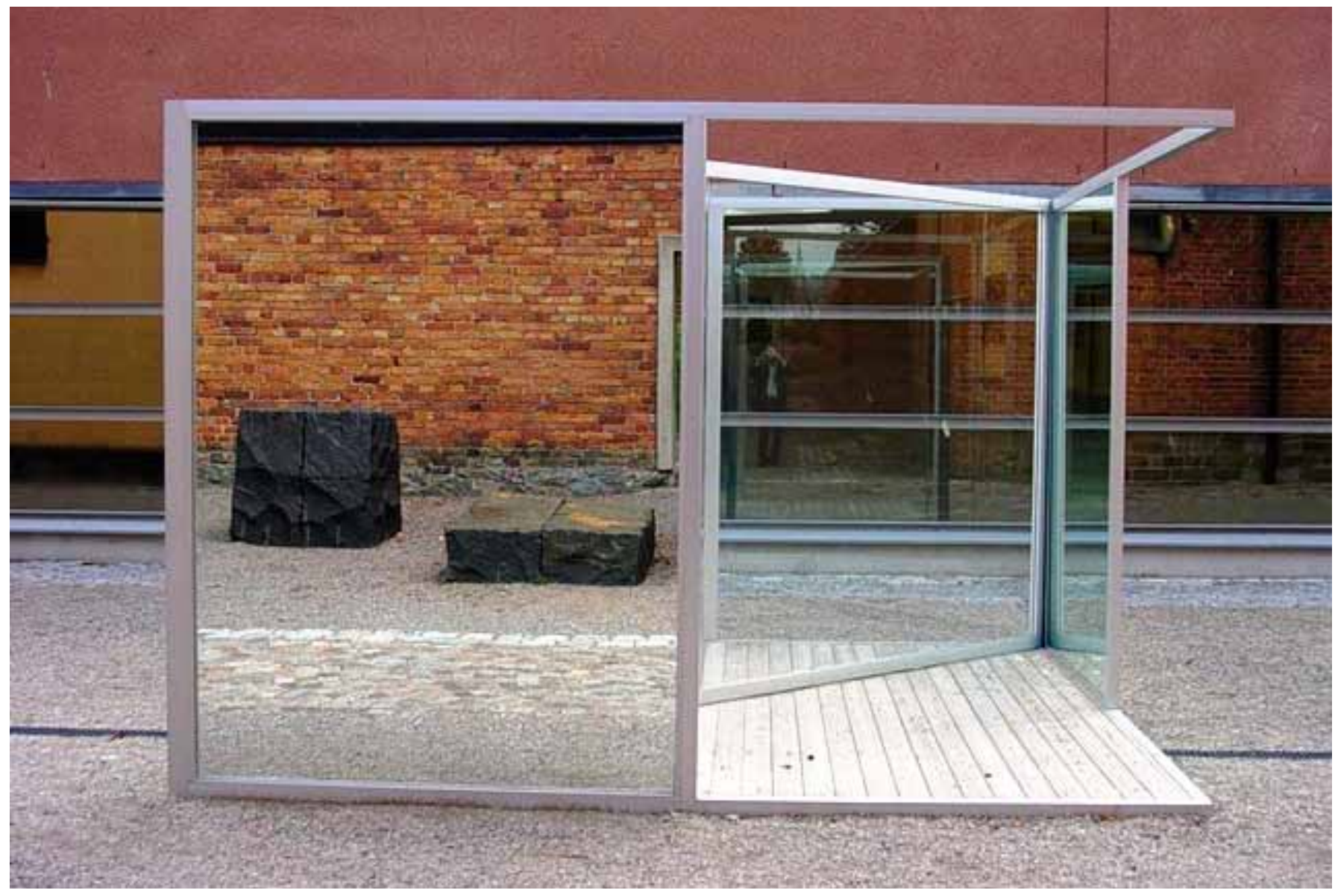

Figure 6.I: Dan Graham, Pavilion Sculpture II, 1984, aluminum, glass, and mirrors, Moderna Museet Sculpture Park, Stockholm. Photograph: Joel Robinson. 
ambience of common representations, where works and wandering visitors find themselves reflected in unassigned encounter.

Some intermediate forerunners to this new condition are the subject of Curtis's recent book, Patio and Pavilion (2007). Here, she examines sculpture's waning yet occasionally still significant role within or around twentieth-century architectural settings, and shows how one remarkable effect of modernist exhibition of sculpture has been to initiate a space for the object's withdrawal in favour of a public represented to itself as attendant subject in the reflexive ambience of the vacated pavilion itself. Curtis opens her observations with Georg Kolbe's figure Morning (1925), poised on the Barcelona Pavilion's pool, reflected among what Robin Evans (1997) called 'Mies' Paradoxical Symmetries'; and closes with Dan Graham reflected in the two-way mirrors of his Two Adjacent Pavilions (1978-82). Between these images, figures and subject positions of sculpture, building, artist, architect and beholder are shown as becoming shifting doubles of each other as the ratio of 'host and guest' alters through a range of situations.

In her opening studies - which take as their subjects Mies and Kolbe, Persico and Fontana, Eliel Saarinen and Carl Milles - Curtis considers cases where architects chose sculpture for their buildings, to add 'something that the architecture alone could not provide', and 'for its difference from their architecture' (Curtis, 2007, p.7). Thus, even as architects sought to resolve it in traditional terms of complementarity, a question of the specificity of art entered, and a question, too, of hierarchy or priority. Was sculpture to serve a setting, or should it be viewed in settings built to serve it? In the second half of her book, Curtis turns to museums and gardens designed as settings for sculpture - for example, Mies's Museum for a Small City project of 1943, Cullinan Hall of 1958, and the Berlin Nationalgalerie of 1968; Philip Johnson's MoMA sculpture garden of 1953; Carlo Scarpa's Gipsoteca Canoviana of 1957; the Sonsbeek pavilions by Gerrit Rietveld (1955) and Aldo Van Eyck (1965); and Peter and Alison Smithson's Patio and Pavilion project, with Nigel Henderson's sculpture and print for the Independent Group's 1956 exhibition This Is Tomorrow.

Yet each of these projects claimed their own autonomy, especially where freestanding open-plan elements became in effect sculptures in their own right. Here, Curtis remarks, 'the essential ability of sculpture and architecture to complement one another is demonstrated, rather, in their collapse into one another' (2007, p.9). Moreover, with its scattered junk objects among artworks in a 'backyard shed', the
Smithsons' Patio and Pavilion realized the Independent Group's project for a 'Parallel of Art and Life', while its aluminium fence reflected visitors into becoming participant subjects in a place designed 'to include every visitor as an inhabitant' (Peter and Alison Smithson, cited in Curtis, p. 135). Thus, moves to distinguish specificity in each art led paradoxically to what Thierry de Duve (1983) named as the theme of Dan Graham's Mirror Performances - i.e., 'The Critique of Artistic Autonomy'.

Rather than trace crises of autonomy in the 'expanded field' of site-specific works, Curtis stays with the 'non-site' of the gallery, to attend to what may at first seem a minor phenomenon - the pavilion. Yet, 'minor' can hardly describe what was, in Abbé Laugier's 'primitive hut', a foundational myth of modern architecture, and became in the Barcelona Pavilion, its epitome. For, what emerges in Patio and Pavilion is how the open plan became both lens and stage, so that every presence entering it became both object and subject of aesthesis. Within and around the 'primitive hut' pavilion, the open plan made of architecture's minimal mode a site for sculpture's potential as performance. The sculpted figures in the MoMA garden, Curtis writes, 'punctuate and articulate a blank open space broken up by occasional blocks and screens. [They] reveal its spatial layering... as if... in a model theatre.' (p.75).

When Laugier wrote his Essai (I753), buildings were aswarm with sculptures - caryatids, herms, atlantes - that displayed architecture's enframing role in schemes of art. Then, after Lessing's claim, in Laokoon, oder über die Grenzen der Mahlerey und Poesie (I766), for the specificity of each art, sculpture was increasingly detached from buildings; the eminent adornment of beaux-arts walls became theatrically deep relief. The nineteenth-century formalist Adolf Hildebrand was concerned to confirm relief in planar, not three-dimensional space. He criticized Canova's Maria Christina tomb (1805) for detaching its figures from the plane of the monument. 'So long as a threedimensional figure is seen primarily as cubic, it is still in the initial stages of its formation. Only when it works as a plane, although still cubic, does it acquire artistic form; that is, only then does it mean something to the spatial imagination' (Hildebrand, [1893] 1994, pp.227-9). When describing how this ideal spatial image emerged in a three-dimensional figure, he sited it, as it were, in a vitrine or aquarium, by imagining it between two parallel panes, so that its outermost points touch the glass. 'The figure then occupies and describes a place of uniform depth, within which its component parts are arranged. Seen from the front through the glass, the 
figure is coherent, first as an identifiable object within a uniform planar stratum, second as a volume defined by the uniform depth of the general volume' (p.25I). Even a three-dimensional sculpture is viewed by Hildebrand as a multiple relief, as if sliced by glass layers, from which depth or space recedes: 'The total volume of the picture ... consists of a number of such imaginary strata placed one behind another in a series and again made coherent as one appearance of uniform depth.'

Certainly, notable use was made by some twentiethcentury artists of a cage or vitrine, either as poetic micro-stage, or to frame an object as form in the way described by Hildebrand. Alberto Giacometti did both; in a surrealist work like The Palace at 3am (1932), then in paintings, and in his sculpture The Nose (1947). Francis Bacon repeatedly twisted his turbulent figures within projected vitrines/cages. With Joseph Cornell's boxes, no less interesting is how their 'museum rooms' relate to Donald Judd's concerns with boxes stacked in series but to Judd's expansion of the vitrine to a nineteenth-century glass and iron building in his $\mathrm{SoHo}$ museum, and to the 'extended pavilion' of his Marfa Chinati Foundation. As for Philip Johnson's house, its vitrine framed not only figures by Elie Nadelman and Giacometti but the highly self-performed figure of Johnson himself. Curtis perceptively remarks that 'abstract architecture is well-suited to (or even requires) figuration'; but, noting the careful photos of Johnson at his window on a grey day, bare trees reflected in the glass across his balefully 'existential' gaze, we can suggest further that, like a lens, the vitrine pavilion dilated the figuratively posed persona that flourishes in a media-saturated age, and which in Andy Warhol's serialized clichés, became 'iconic'. And Warhol recognized this; for he took care on visiting the house to have a photo taken of himself in Johnson's pose from outside, with him staring from within, greyly out through the glass wall. ${ }^{2}$

In Curtis's book, the vitrine appears most spatially engaged in the Canova museum, where four perlucid prisms overlap in perspective in a wing itself sky-lit by re-entrant vitrine lanterns, revealing itself to a visitor moving among the sculptures as itself a larger, enframing vitrine. Other of Curtis's examples appear as variants on a vitrine. Dan Graham, self-photographing, stands amid mutual reflections in the two-way mirrors of his Two Adjacent Pavilions, which recede in parallel planes like the panes described by Hildebrand. And

I Hildebrand's model of phenomenal layers anticipated ideas developed by Colin Rowe and Robert Slutzky in their 1983 essay 'Transparency, Literal and Phenomenal.'

2 A sustained analysis of Johnson's house was made by Jeff Wall in his 1985 essay 'Dan Graham's Kammerspiel'.
Van Eyck's pavilion would present, if its parallel and permeable walls were glass, a vitrine for Hildebrand's ideal model of relief. Yet here Curtis finds 'a sense that the sculptures detract from the pavilion itself'. Thrown into relief by the pavilion are not the sculptures, but its visitors' figures as they wander through Van Eyck's 'kaleidoscopic and labyrinthine' spaces (Aldo Van Eyck, cited in Curtis, 2007, p. 124).

Among Curtis's case-studies, however, it was Mies who most consistently developed a spatial ideal as if drawn from Hildebrand's vitrine model. From the mid-1920s, Mies turned from architecture as figure (as in his 'expressionist' glass skyscrapers of 1920) to conceiving architecture as a frame for the figure. In this he drew out an implication in August Schmarsow's redefinition of architecture as 'creatress of space'. The figure no longer is the building (its surface now becoming 'ground') but what it frames: space. Framed, and indeed staged - for it thereby opens a 'clearing' for a new event. What this was to be was impossible to determine by functional analysis. Hence the significance as 'symbolic form' (to use Erwin Panofsky's term) of the 'open plan'; and, as Curtis shows, the tactical value of figurative sculptures, which in Mies's drawings enter as a general or null signifier for a an unknown subject amid a transcendent but unassignable Stimmung.

A consequence was Mies's turn in his interior drawings and montages to stage-design, nearly always in central perspective, with the furthest plane, as in Hildebrand's model parallel to the foremost picture plane; and between them, like isolated culisses slid out onto a bare stage, a few sparse planes and figures; the planes are abstract paintings, or wood or stone screens, the figures are always statues. Mies wrote in a 1943 essay titled 'New Buildings for 194X' published in Architectural Forum that in a 'garden [openplan] approach to the display of sculpture', 'interior sculptures enjoy an equal spatial freedom, because the open plan permits them to be seen against the surrounding hills. The architectural space thus achieved, becomes a defining rather than confining space' (cited in Curtis, 2007, p.59). For Mies, the furthest plane was landscape, or a low wall with sky or woods beyond. Or, the landscape was a wall, as in his montage for the Resor House (1937-9), which places us within and looking out through a panoramic glass wall at a vista of mountains, continuous but for four slender vertical cuts like the 'zips' in Barnett Newman's paintings. It may be that Mies's autumn 1947 MoMA exhibition, which showed the Resor montage, influenced Newman's start in early 1948 on his austerely abstract colourfields. Moreover, in relation to the idea of the figure in an open-plan sculpture pavilion becoming the beholder, 
Hans Namuth's photographs of viewers in Newman's exhibitions are remarkable. Backs to the camera, absorbed in the 'abstract sublime', they resemble those mountain wanderers in Caspar David Friedrich's paintings. It is as if the summit brink has become the pictureplane, or as in the Resor House, the glass wall between us and the mountains. As if to confirm this, Namuth made a photograph of Newman doubleexposed onto his own painting, so that it is as if we have gone around to the other side of the pane, where we see him looking at us, out through a glass wall. ${ }^{3}$

An ultimate reflexive version of vitrine-as-stage, albeit not discussed in Curtis's book, might be Dan Graham's Performance Audience Mirror of 1978. Here, performer and audience are both alternately figure and ground, but are framed neither as actor on a Serlian stage nor as object in a vitrine for contemplation by a sovereign subject. Nor can either adopt Friedrich's or Newman's position of a wanderer beholding a sublime beyond. Graham, standing before a mirror which, as scenae frons, reflects the audience to themselves, describes first himself and then the audience.Then, turning his back to the audience to see them and himself in the mirror, he repeats his descriptions, but now via the mirror's reflections. As the alternating descriptions go on, they induce a behavioural feedback, conjoining performer and all audience subjects in a loop of response and anticipation; until, as De Duve (1983) put it, "the here and now are produced by the experience whose precondition they are... The identity of the performer is a projection whose "place" is the audience, and vice versa'. The Serlian stage and open plan are mobilized in an open loop where relief is cast into relief, and common awareness made a figure in the round whose frame of reference is no longer a vitrine but intersubjective time.

\section{Bibliography}

I Curtis, P. (2007) Patio and Pavilion, London, Ridinghouse.

2 De Duve,T. (1983) 'Dan Graham and the critique of artistic autonomy,' in J.-H. Hubert (ed.) Dan Graham Pavilions, exhibition catalogue, Kunsthalle Bern.

3 De Duve,T. ([1983] 200I) 'Dan Graham and the critique of artistic autonomy' in M. Brouwer (ed.) Dan Graham Works 1965-2000, exhibition catalogue, Düsseldorf, Richter Verlag, pp.49-66.

4 De Duve, T. (1993) 'Ex itu’ in A. Benjamin (ed.) Installation Art, London, A\&D Academy, pp.25-30.

5 Evans, R. (1997) 'Mies' paradoxical symmetries', Translations from Drawing to Building and Other Essays, London, Architectural Association Documents, No.2, Pp.223-76.

6 Hildebrand,A. ([1893] 1994) 'The problem of form in the fine arts' in H.F.Mallgrave and E. lknonomou (eds) Empathy, Form, and Space, Santa Monica, Getty Research Institute for the History of Art and the Humanities, Pp.227-9.

7 Krauss, R. (1979) 'Sculpture in the expanded field', October, vol.8, Spring, pp.30-44.

8 Krauss, R. (1986) The Originality of the Avant-Garde, and Other Modernist Myths, Cambridge, MA, MIT Press.

9 Lum, E. (1999) 'Pollock's promise:Towards an Abstract Expressionist architecture', Assemblage 39, pp.62-93.

10 Panofsky, E. (1927) Perspective as Symbolic Form (trans. C.Wood), Cambridge, MA, MIT Press.

II Rowe, C. and Slutzky, R. (1983) 'Transparency, literal and phenomenal' in B. Hoesli (ed.) Transparency, London, St.Martin's Press.

12 Wall,J. (1985) 'Dan Graham's Kammerspiel', Real Life, nos. 14 \& 15 .

3 In fact, there was one explicit project to place abstract expressionist painting within a Miesian glass pavilion, namely Peter Blake's project for a gallery devoted to Jackson Pollock, exhibited at Betty Parson's gallery in New York in 1950. On this subject, see Eric Lum's 1999 essay 'Pollock's Promise: Towards an Abstract Expressionist Architecture'. 